\title{
Dukungan Suami dalam Pemberian ASI Eksklusif di Wilayah Kerja Puskesmas Air Tawar Kota Padang, Sumatera Barat
}

\author{
Mery Ramadani*, Ella Nurlaella Hadi**
}

\begin{abstract}
Abstrak
Manfaat pemberian ASI yang sangat besar ternyata belum mampu meningkatkan angka cakupan ASI eksklusif. Hal tersebut terlihat pada tingkat pemberian ASI eksklusif di tanah air yang masih rendah berada pada kisaran 39\%-40\%. Tujuan penelitian ini mengetahui dukungan suami dalam pemberian ASI eksklusif di Wilayah Kerja Puskesmas Air Tawar, Kota Padang Tahun 2009. Rancangan penelitian potong lintang digunakan pada bulan Maret-April 2009 dengan responden ibu bayi usia 7-12 bulan. Hasil penelitian mendapatkan $55,4 \%$ ibu memberikan ASI eksklusif dan $57 \%$ ibu mendapat dukungan suami dalam pemberian ASI eksklusif. Ada hubungan antara dukungan suami dengan pemberian ASI eksklusif, ibu yang suaminya mendukung pemberian ASI eksklusif berpeluang memberikan ASI eksklusif 2 kali daripada ibu yang suaminya kurang mendukung pemberian ASI eksklusif setelah dikontrol oleh pekerjaan suami, dukungan petugas kesehatan, dan pekerjaan ibu. Oleh karena peran suami penting dalam pemberian ASI eksklusif, maka suami harus dijadikan sasaran penyuluhan ASI dan didorong untuk lebih aktif mencari informasi serta aktif belajar mengenai ASI, sehingga lebih paham dalam memberikan dukungan kepada ibu untuk menyusui secara eksklusif.
\end{abstract}

Kata kunci: ASI eksklusif, dukungan suami

\section{Abstract}

The objective of this study was to know husband's support in exclusive breastfeeding at working areas of Puskesmas Air Tawar, Padang in 2009. Cross sectional design was used in this study that was conducted from March to April 2009. The respondents were mothers with baby of 7 to 12 months. This study found out that $55.4 \%$ of mothers did exclusive breastfeeding, and $57 \%$ mothers gained husband's support in exclusive breastfeeding. There was a relationship between husband's support and exclusive breastfeeding whereas mothers who had husbands' support likely do exclusive breastfeeding two times than mothers without husband's support after adjusted by husband's occupation, health provider's support and mother's occupation. As the role of husband is important in exclusive breastfeeding, therefore husbands should became the target of education on exclusive breastfeeding and encourage them to be more active in searching information about exclusive breastfeeding, so that they would support their wives in exclusive breastfeeding.

Key words: Exclusive breastfeeding, husband's support 
Manfaat praktek pemberian ASI yang sangat besar ternyata belum mampu meningkatkan angka cakupan ASI eksklusif. Hal ini dapat dilihat dari masih rendahnya tingkat pemberian ASI eksklusif di tanah air yang masih berkisar antara 39-40\%.1 Survei oleh Nutrition \& Health Surveillance System (NSS) bekerja sama dengan Balitbangkes dan Helen Keller International di Jakarta, Surabaya, Semarang, Makasar dan delapan pedesaan (Sumbar, Lampung, Banten, Jabar, Jateng, Jatim, NTB, Sulsel) yang dilaksanakan pada tahun 2002, menunjukkan cakupan ASI eksklusif 4-5 bulan di perkotaan antara 4$12 \%$, sedangkan di pedesaan $4-25 \%$. Pencapaian ASI eksklusif $5-6$ bulan di perkotaan sekitar $1-13 \%$ dan di pedesaan 2-13\%. ${ }^{2}$ Data UNICEF tahun 2007 menunjukkan angka cakupan ASI eksklusif di Indonesia sebesar 32\%.3

Seminar memperingati Pekan ASI Sedunia tahun 2008 mengemukakan banyak faktor yang menjadi masalah pemberian ASI yang rendah di Indonesia, salah satu faktor pendukung adalah suami yang merupakan orang terdekat yang memainkan peran kunci selama kehamilan, persalinan dan setelah bayi lahir termasuk pemberian ASI. ${ }^{4}$ Dukungan yang diberikan suami akan mempengaruhi kondisi psikologis ibu yang akan berdampak terhadap keberhasilan menyusui. ${ }^{5}$ Suami merupakan faktor pendukung pada kegiatan yang bersifat emosional dan psikologis yang diberikan kepada ibu menyusui. Sekitar $80 \%$ sampai $90 \%$ produksi ASI ditentukan oleh keadaan emosi ibu yang berkaitan dengan refleks oksitosin ibu berupa pikiran, perasaan dan sensasi. Apabila hal tersebut meningkat akan memperlancar prosuksi ASI. ${ }^{6}$ Di Australia, praktek pemberian ASI eksklusif terbukti 1,5 kali lebih berhasil apabila didukung oleh suami. ${ }^{7}$ Angka keberhasilan menyusui bayi sampai 6 bulan meningkat pada kelompok studi yang mengikutsertakan ayah dan ibu dalam konseling menyusui dibanding kelompok studi yang hanya diikuti oleh ibu. ${ }^{8}$ Studi di daerah urban Jakarta dan Kabupaten Pidie Jaya, Aceh, membuktikan dukungan suami berhubungan dengan keberhasilan pemberian ASI eksklusif. 9,10 Dukungan suami membuat ibu berpeluang 5,1 kali lebih besar untuk memberikan ASI eksklusif daripada yang tidak didukung suami. ${ }^{9}$

Sumatera Barat merupakan salah satu propinsi dengan cakupan ASI eksklusif yang masih rendah. Laporan tahunan Dinas Kesehatan Propinsi Sumatera Barat tahun 2004 menunjukan cakupan ASI eksklusif 19,1\%; sedangkan cakupan di wilayah kerja puskesmas Air Tawar, Kota Padang sebesar 60\%. Walaupun masih berada di bawah target nasional $(80 \%)$, tetapi tiga kali lebih besar daripada cakupan propinsi Sumatera Barat $(19,1 \%)$. Puskesmas Air Tawar terletak di daerah perkotaan dengan pekerjaan suami yang bervariasi, tetapi hubungan dukungan suami dengan praktek pemberian ASI eksklusif di wilayah tersebut belum diketahui. Untuk itu perlu dilakukan penelitian tentang dukungan suami dalam praktek pemberian ASI eksklusif setelah dikontrol oleh faktor-faktor lain yang diduga berkontribusi. Faktor tersebut meliputi pengetahuan, sikap, rencana pemberian ASI eksklusif, paritas, pekerjaan ibu, pekerjaan suami, pendidikan suami, dan dukungan petugas kesehatan.

\section{Metode}

Penelitian ini menggunakan disain potong lintang, pada 186 ibu bayi 7-12 bulan yang berada di wilayah kerja Puskesmas Air Tawar, Kota Padang. Data dikumpulkan pada bulan Maret-April 2009 dengan metode wawancara menggunakan kuesioner yang sebelumnya telah diujicobakan di wilayah kerja Puskesmas Alai yang mempunyai karakteristik yang hampir sama dengan Puskesmas Air Tawar. Data dianalisis dengan menggunakan regresi logistik ganda. Perhitungan odds ratio (OR) dilakukan dengan mengontrol variabel kovariat yang bermakna secara statistik (nilai $\mathrm{p}<0,05$ ) dan dicurigai mengganggu hubungan antara dukungan suami dengan pemberian ASI eksklusif. ${ }^{10}$

\section{Hasil \\ Pemberian ASI Eksklusif, Dukungan Suami dan Variabel Kovariat}

Sebanyak 55,4\% ibu memberikan ASI eksklusif dan $57 \%$ ibu menyatakan suaminya mendukung pemberian ASI eksklusif. Lebih dari separuh ibu $(54,8 \%)$ mempunyai pengetahuan rendah tentang ASI, bersikap negatif terhadap pemberian ASI eksklusif $(64,5 \%)$. Sebagian besar ibu $(76,3 \%)$ sudah merencanakan akan memberikan ASI eksklusif kepada bayinya, paling banyak memiliki 2 anak $(93 \%)$ dan tidak bekerja $(58,1 \%)$. Sebagian besar ibu $(83,9 \%)$ mempunyai suami berpendidikan dan suaminya memiliki penghasilan tetap $(84,9 \%)$. Namun demikian, lebih dari separuh ibu $(54,8 \%)$ mengatakan kurang mendapat dukungan dari petugas kesehatan untuk memberikan ASI eksklusif (Lihat Tabel 1).

\section{Analisis Bivariat}

Analisis bivariat menunjukkan variabel dukungan suami $(p<0,0005)$, dan lima variabel kovariat meliputi rencana pemberian ASI eksklusif ( $p<0,0005)$, pekerjaan ibu $(p=0,021)$, pekerjaan suami $(p=0,039)$, pendidikan suami $(\mathrm{p}=0,040)$ dan dukungan petugas kesehatan $(\mathrm{p}=$ $0,004)$ memenuhi kriteria kandidat model multivariat (nilai $\mathrm{p}<0,25$ ) (Lihat Tabel 2).

\section{Analisis Multivariat \\ Hierarchically Well Formulated (HWF) Model}

Langkah pertama dalam pemodelan untuk menguji 
Tabel 1. Proporsi Pemberian ASI Eksklusif, Dukungan Suami dan Karakteristik Ibu $(\mathbf{N}=186)$

\begin{tabular}{lll}
\hline Variabel & Katagori & (\%) \\
\hline Pemberian ASI eksklusif & Eksklusif & 55,4 \\
& Tidak eksklusif & 44,6 \\
Dukungan suami & Mendukung & 57,0 \\
& Tidak mendukung & 43,0 \\
Pengetahuan ibu & Baik & 45,2 \\
Sikap ibu & Kurang baik & 54,8 \\
& Positif & 35,5 \\
Rencana pemberian ASI & Negatif & 64,5 \\
& Ada & 76,3 \\
Paritas & Tidak ada & 23,7 \\
Pekerjaan ibu & Banyak & 7,0 \\
Pekerjaan suami & Sedikit & 93,0 \\
Pendidikan suami & Tidak bekerja & 58,1 \\
& Bekerja & 41,9 \\
Dukungan petugas kesehatan & Penghasilan tetap & 84,9 \\
& Penghasilan tidak tetap & 15,1 \\
& Tinggi & 83,9 \\
\hline
\end{tabular}

Tabel 2. Analisis Bivariat untuk Seleksi Variabel Kandidat Model Multivariat Pemberian ASI Eksklusif

\begin{tabular}{|c|c|c|}
\hline Variabel & Katagori & Nilai p \\
\hline Dukungan suami & $\begin{array}{l}\text { Mendukung } \\
\text { Tidak }\end{array}$ & $<0,0005$ \\
\hline Pengetahuan & $\begin{array}{l}\text { Baik } \\
\text { Kurang }\end{array}$ & 0,140 \\
\hline Sikap & $\begin{array}{l}\text { Positif } \\
\text { Negatif }\end{array}$ & 0,988 \\
\hline Rencana beri ASI & $\begin{array}{l}\text { Ada } \\
\text { Tidak ada }\end{array}$ & $<0,0005$ \\
\hline Paritas & $\begin{array}{l}\text { Banyak } \\
\text { Sedikit }\end{array}$ & 0,326 \\
\hline Pekerjaan ibu & $\begin{array}{l}\text { Tidak kerja } \\
\text { Bekerja }\end{array}$ & 0,021 \\
\hline Pekerjaan suami & $\begin{array}{l}\text { Tetap } \\
\text { Tidak tetap }\end{array}$ & 0,039 \\
\hline Pendidikan suami & $\begin{array}{l}\text { Tinggi } \\
\text { Rendah }\end{array}$ & 0,040 \\
\hline Dukungan Nakes & $\begin{array}{l}\text { Mendukung } \\
\text { Kurang }\end{array}$ & 0,004 \\
\hline
\end{tabular}

hipotesis adalah membuat model yang mengikutsertakan semua kovariat dan interaksi. Pada penelitian ini interaksi yang mungkin terjadi antara kovariat dengan variabel independen utama (dukungan suami) adalah dukungan suami dengan pekerjaan suami dan dukungan suami dengan pendidikan suami. Untuk itu model yang terbentuk adalah seperti pada Tabel 3.

\section{Uji Interaksi}

Setelah didapatkan model HWF dilakukan uji interaksi, dengan mengeluarkan satu persatu variabel interaksi yang mempunyai nilai $\mathrm{p}>0,05$ pada model, dimulai dari variabel interaksi yang memiliki nilai $\mathrm{p}$ terbesar. Urutan pengeluaran variabel interaksi dari model adalah sebagai berikut: 1) interaksi dukungan suami dengan pendidikan suami ( $\mathrm{p}=0,719) ; 2)$ interaksi dukungan suami dengan pekerjaan suami $(p=0,596)$. Hasil analisis membuktikan tidak ada interaksi antara dukungan suami dengan pendidikan suami dan antara dukungan suami dengan pekerjaan suami, sehingga keduanya dikeluarkan dari model dan diperoleh model baku emas (Lihat Tabel 4).

\section{Penilaian Confounder}

Model selanjutnya disederhanakan dengan mengurangi variabel kovariat atau confounder pada hubungan antara dukungan suami dengan pemberian ASI eksklusif. Pengurangan confounder dimulai dari confounder yang memiliki nilai $\mathrm{p}$ terbesar dengan urutan seperti yang terlihat pada Tabel 5. Dari 8 variabel yang diduga sebagai confounder pada hubungan antara dukungan suami dengan pemberian ASI eksklusif, ternyata hanya 3 variabel yang merupakan confounder, yaitu pekerjaan suami, dukungan petugas kesehatan dan pekerjaan ibu (Lihat Tabel 5). Pada variabel-variabel lainnya, karena perubahan OR relatif $<10 \%$, maka variabel-variabel tersebut bukan merupakan confounder, sehingga dapat dikeluarkan dari model.

Model akhir hubungan dukungan suami dengan pemberian ASI eksklusif adalah seperti yang terlihat pada Tabel 6. Dukungan suami berhubungan dengan pemberian ASI eksklusif setelah dikontrol oleh pekerjaan suami, pekerjaan ibu dan dukungan petugas kesehatan. Ibu yang mendapat dukungan suami berpeluang memberikan ASI eksklusif 2 kali dibanding ibu yang kurang mendapat dukungan suami setelah dikontrol oleh pekerjaan suami, pekerjaan ibu dan dukungan petugas kesehatan (Lihat Tabel 6).

\section{Pembahasan}

Hasil penelitian ini menemukan 55,4\% ibu memberikan ASI eksklusif, sedangkan 44,6\% ibu lainnya sudah memberikan susu formula dan atau makanan pendamping ASI sebelum bayi mereka berusia 6 bulan. Cakupan pemberian ASI eksklusif sampai bayi berumur 6 bulan di Propinsi Sumatera Barat masih jauh dari target nasional (80\%). ${ }^{2}$ Meskipun demikian, hasil ini masih lebih tinggi jika dibandingkan dengan hasil penelitian lain yang menemukan cakupan ASI di daerah perkotaan Sumatera Barat sebesar 29,4\%.11 Angka cakupan yang tinggi ini bisa disebabkan lokasi Puskesmas Air Tawar yang terletak di tengah kota yang memungkinkan masyarakat lebih mudah dan cepat dalam menerima informasi, termasuk informasi mengenai ASI eksklusif. Tingkat pendidikan masyarakat yang mayoritas tinggi juga berkontribusi secara tidak langsung terhadap 
Tabel 3. Model dengan Semua Potensial Confounder dan Interaksi

\begin{tabular}{|c|c|c|c|c|c|c|}
\hline Variabel & B & SE & Wald & Df & p value & OR \\
\hline Dukungan suami & 0,702 & 0,392 & 3,200 & 1 & 0,074 & 2,017 \\
\hline Pengetahuan ibu & 0,307 & 0,351 & 0,764 & 1 & 0,382 & 1,360 \\
\hline Sikap ibu & $-0,161$ & 0,375 & 0,183 & 1 & 0,668 & 0,852 \\
\hline Rencana pemberian ASI & 1,605 & 0,420 & 14,626 & 1 & 0,000 & 4,978 \\
\hline Paritas & $-0,586$ & 0,707 & 0,687 & 1 & 0,407 & 0,557 \\
\hline Pekerjaan ibu & 0,868 & 0,361 & 5,779 & 1 & 0,016 & 2,383 \\
\hline Pekerjaan suami & 0,496 & 0,747 & 0,440 & 1 & 0,507 & 1,641 \\
\hline Pendidikan suami & 0,857 & 0,710 & 1,457 & 1 & 0,227 & 2,355 \\
\hline Dukungan petugas kesehatan & 0,827 & 0,372 & 4,945 & 1 & 0,026 & 2,288 \\
\hline Dukungan suami*pekerjaan suami & 0,649 & 1,073 & 0,365 & 1 & 0,546 & 1,913 \\
\hline Dukungan suami*pendidikan suami & $-0,364$ & 0,010 & 0,130 & 1 & 0,719 & 0,695 \\
\hline Konstanta & $-1,446$ & 0,837 & 2,984 & 1 & 0,084 & 0,236 \\
\hline
\end{tabular}

Tabel 4. Model Baku Emas

\begin{tabular}{lllllll}
\hline Variabel & B & SE & Wald & Df & p value & OR \\
\hline Dukungan suami & 0,702 & 0,392 & 3,200 & 1 & 0,074 & 2,017 \\
Pengetahuan ibu & 0,307 & 0,351 & 0,764 & 1 & 0,382 & 1,360 \\
Sikap ibu & $-0,161$ & 0,375 & 0,183 & 1 & 0,668 & 0,852 \\
Rencana pemberian ASI & 1,605 & 0,420 & 14,626 & 1 & 0,000 & 4,978 \\
Paritas & $-0,586$ & 0,707 & 0,687 & 1 & 0,407 & 0,557 \\
Pekerjaan ibu & 0,868 & 0,361 & 5,779 & 1 & 0,016 & 2,383 \\
Pekerjaan suami & 0,496 & 0,747 & 0,440 & 1 & 0,507 & 1,641 \\
Pendidikan suami & 0,857 & 0,710 & 1,457 & 1 & 0,227 & 2,355 \\
Dukungan petugas kesehatan & 0,827 & 0,372 & 4,945 & 1 & 0,026 & 2,288 \\
Konstanta & $-1,555$ & 0,797 & 3,808 & 1 & 0,051 & 0,211 \\
\hline
\end{tabular}

tingginya angka cakupan ASI, karena seseorang dengan tingkat pendidikan tinggi biasanya mempunyai pengetahuan yang lebih baik.

Hasil studi ini juga membuktikan hubungan antara dukungan suami dengan pemberian ASI eksklusif setelah dikontrol dengan dukungan petugas kesehatan, pekerjaan ibu, dan pekerjaan suami. Ibu yang suaminya mendukung pemberian ASI eksklusif cenderung memberikan ASI eksklusif sebesar 2 kali lebih besar daripada ibu yang suaminya kurang mendukung pemberian ASI eksklusif. Studi di Australia menemukan keberhasilan praktek pemberian ASI eksklusif 1,5 kali lebih besar bila didukung oleh suami. ${ }^{8}$ Temuan yang sama penelitian di Puskesmas Sukarame, Kabupaten Tasikmalaya, keberhasilan pemberian ASI eksklusif 2,9 lebih besar pada kelompok ibu yang mendapat dukungan suami. ${ }^{12}$ Penelitian peran suami selama kehamilan istri sampai dengan melahirkan berhubungan dengan keberhasilan pemberian ASI eksklusif. ${ }^{9}$ Di wilayah kerja Puskesmas Meurah Dua, Kabupaten Pidie, Nangroe Aceh Darussalam, ${ }^{10}$ dukungan suami memberikan peluang kepada ibu untuk memberikan ASI secara eksklusif 5 kali lebih besar daripada ibu yang tidak mendapat dukungan dari suami. ${ }^{11}$
Suami adalah orang terdekat ibu yang banyak berperan selama kehamilan, persalinan dan setelah bayi lahir, termasuk pemberian ASI. Dukungan suami yang diberikan dalam bentuk apapun, dapat mempengaruhi kondisi emosional ibu yang berdampak terhadap produksi ASI. 6 Penelitian ini menemukan hampir seluruh ibu $(93,5 \%)$ di wilayah Puskesmas Air Tawar menilai perhatian yang mereka dapatkan dari suami tidak berkurang, suami tidak pernah mengeluhkan perubahan bentuk tubuhnya setelah melahirkan maupun karena menyusui bayi, bahkan sebanyak $80,6 \%$ ibu menyatakan suaminya menyarankan untuk menyusui bayi.

Penelitian ini menemukan dukungan petugas kesehatan merupakan confounder pada hubungan antara dukungan suami dengan pemberian ASI eksklusif, artinya dukungan petugas kesehatan mempengaruhi dukungan suami dan pemberian ASI eksklusif. Hal ini kemungkinan karena sewaktu ibu memeriksakan kehamilan, bersalin dan kunjungan neonatal, suami ikut mendengarkan penjelasan petugas kesehatan mengenai ASI eksklusif dan manfaatnya, sehingga suami terpengaruh dan termotivasi untuk memberikan dukungan secara maksimal kepada ibu untuk memberikan ASI sampai bayi berumur 6 bulan. Penelitian di Tigaraksa, 
Tabel 5. Penentuan Confounder pada Hubungan antara Dukungan Suami dengan Pemberian ASI Eksklusif di Wilayah Kerja Puskesmas Air Tawar, Kota Padang, 2009

\begin{tabular}{lcccl}
\hline Variabel & OR Crude & OR Adjusted & Perubahan & Keterangan \\
\hline Sikap Ibu & 2,084 & 2,064 & $0,96 \%$ & Bukan confounder \\
Paritas & 2,084 & 2,081 & $0,14 \%$ & Bukan confounder \\
Pengetahuan Ibu & 2,084 & 2,073 & $0,53 \%$ & Bukan confounder \\
Pendidikan Suami & 2,084 & 2,130 & $2,21 \%$ & Bukan confounder \\
Pekerjaan Suami & 2,084 & 2,302 & $10,5 \%$ & Confounder \\
Dukungan Petugas Kesehatan & 2,084 & 2,742 & $31,6 \%$ & Confounder \\
Pekerjaan Ibu & 2,084 & 2,293 & $10,01 \%$ & Confounder \\
\hline
\end{tabular}

Tabel 6. Model Akhir Hubungan Dukungan Suami dengan Pemberian ASI Eksklusif di Wilayah Kerja Puskesmas Air Tawar, Kota Padang, 2009

\begin{tabular}{lcccccc}
\hline Variabel & $\boldsymbol{\beta}$ & SE & Wald & DF & Nilai p & OR \\
\hline Dukungan Suami & 0,783 & 0,336 & 5,423 & 1 & 0,020 & 2,187 \\
Pekerjaan Suami & 1,233 & 0,474 & 6,771 & 1 & 0,009 & 3,430 \\
Dukungan Petugas Kesehatan & 0,736 & 0,339 & 4,716 & 1 & 0,030 & 2,087 \\
Pekerjaan Ibu & 0,782 & 0,329 & 5,635 & 1 & 0,018 & 2,186 \\
Konstanta & $-1,449$ & 0,306 & 22,409 & 1 & 0,000 & 0,235 \\
& & & & & &
\end{tabular}

Tangerang juga membuktikan hubungan antara dukungan petugas kesehatan dengan keberhasilan ASI eksklusif. ${ }^{13}$ Ibu yang merasa mendapat konseling menyusui yang baik dari petugas kesehatan, berpeluang 2,4 kali lebih berhasil dalam memberikan ASI eksklusif dibandingkan yang mendapat konseling kurang baik dari petugas kesehatan. ${ }^{14} \mathrm{Hal}$ ini karena petugas kesehatan seperti perawat, bidan atau dokter merupakan orang pertama yang membantu ibu bersalin untuk memberikan ASI kepada bayinya. ${ }^{15}$ Untuk itu, petugas kesehatan harus mengetahui tatalaksana laktasi yang baik dan benar, di samping bersikap positif terhadap pemberian ASI, sehingga dapat mempengaruhi pemberian ASI eksklusif. Petugas kesehatan harus memberikan penjelasan tentang ASI secara sinambung, mulai dari pemeriksaan kehamilan, setelah persalinan dan saat kunjungan neonatal. Untuk itu, petugas kesehatan harus memiliki keterampilan dalam konseling ASI, baik dalam hal berkomunikasi, pengetahuan tentang pemberian ASI secara medis/teknis, sosial budaya dan agama, serta memahami program pemberian ASI yang dilakukan pemerintah dan masyarakat. ${ }^{16}$

Pekerjaan suami merupakan confounder pada hubungan dukungan suami dengan pemberian ASI eksklusif yang mempengaruhi dukungan suami sekaligus mempengaruhi pemberian ASI eksklusif. Kesibukan suami dalam mencari nafkah merupakan salah satu hambatan yang dihadapi suami dapat untuk lebih terlibat dalam keluarga. ${ }^{17}$ Untuk mengatasi hambatan ini diperlukan tindakan yang tepat, seperti mempromosikan ASI eksklusif di tempat kerja suami dan mendorong suami untuk berpartisipasi aktif dan menemani ibu saat pemeriksaan kehamilan, persalinan dan saat kunjungan neonatal. Suami dengan pekerjaan dan penghasilan tetap mempunyai waktu yang relatif teratur setiap hari, sehingga memungkinkan suami lebih terlibat dalam keluarga dan pengasuhan bayi termasuk pemberian ASI eksklusif. Penghasilan tetap yang diperoleh suami setiap bulan, memberi kesempatan untuk mendukung pemenuhan kebutuhan gizi ibu setiap hari. Beberapa penelitian membuktikan hubungan antara pekerjaan suami dengan perilaku menyusui ibu, suami yang bekerja tetap berhubungan positif dengan keberhasilan ibu dalam menyusui secara eksklusif. 9,18

Besar peluang ibu dalam memberikan ASI eksklusif juga dipengaruhi oleh pekerjaan ibu. Ibu yang bekerja mencari nafkah cenderung menjadi penyebab kegagalan pemberian ASI eksklusif. Hasil penelitian ini membuktikan pekerjaan ibu merupakan confounder pada hubungan antara dukungan suami dengan pemberian ASI eksklusif. Ibu yang bekerja mempunyai waktu yang terbatas untuk keluarga dan terbagi dengan urusan pekerjaan di luar rumah, otomatis tidak dapat sehari penuh terlibat dalam pengasuhan anak. Keadaan ini memerlukan dukungan dan kesediaan suami untuk bekerja sama dalam hal pengasuhan anak dan pemberian ASI. Selama ibu berada di tempat kerja, suami dapat menggantikan peran ibu memberikan ASI peras atau mengambil alih 
pekerjaan rumah tangga, sehingga sesampainya di rumah ibu berkesempatan untuk memberikan ASI secara langsung dan bermain dengan bayi tanpa harus direpotkan lagi dengan pekerjaan rumah tangga. Studi di Cina telah membuktikan, ibu yang tidak bekerja berpeluang $1,2 \mathrm{kali}$ untuk menyusui eksklusif dibanding ibu yang bekerja, karena ibu yang tidak bekerja mempunyai waktu lebih banyak bersama bayi, dibandingkan ibu yang bekerja. ${ }^{16,19}$ Lokasi tempat kerja yang jauh dari rumah menyebabkan ibu beralih ke susu formula disamping karena tidak tersedianya waktu dan tempat yang nyaman untuk memeras ASI di tempat kerja.

Penelitian ini mendapatkan bahwa pengetahuan dan sikap ibu bukan confounder pada hubungan antara dukungan suami dengan pemberian ASI eksklusif. Dukungan suami dan praktek pemberian ASI eksklusif tidak hanya dipengaruhi oleh pengetahuan dan sikap ibu tetapi kemungkinan juga oleh keluarga besar seperti ibu/ mertua. Rencana pemberian ASI eksklusif juga bukan confounder pada hubungan antara dukungan suami dengan pemberian ASI eksklusif. Hal ini berarti rencana pemberian ASI tidak mempengaruhi dukungan suami dan pemberian ASI eksklusif. Hal ini kemungkinan karena pengaruh keluarga besar, sehingga ibu dan suami yang tadinya berencana untuk memberikan ASI eksklusif tidak dapat mewujudkan rencananya. Hasil penelitian ini juga menemukan paritas bukan confounder pada hubungan antara dukungan suami dengan pemberian ASI eksklusif, karena hampir semua ibu memiliki anak sedikit (1-2) orang sehingga tidak ada variasi.

\section{Kesimpulan}

Sebanyak 55,4\% ibu memberikan ASI eksklusif kepada bayinya karena 57\% ibu mengatakan mendapat dukungan dari suaminya. Ada hubungan antara dukungan suami dengan pemberian ASI eksklusif dimana ibu yang mendapat dukungan dari suami mempunyai kecenderungan untuk memberikan ASI secara eksklusif sebesar 2 kali dibanding ibu yang kurang mendapat dukungan dari suaminya setelah dikontrol pekerjaan suami, dukungan petugas kesehatan, dan pekerjaan ibu.

\section{Saran}

Suami berperan penting dalam pemberian ASI eksklusif, oleh sebab itu suami harus dijadikan sasaran penyuluhan ASI dan didorong untuk lebih aktif mencari informasi serta aktif belajar mengenai ASI, sehingga lebih paham dalam memberikan dukungan kepada ibu untuk menyusui eksklusif.

\section{Daftar Pustaka}

1. Departemen Kesehatan RI. Hidup ASI eksklusif [edisi 2005]. Diunduh dari: http://www.republika.co.id.koran-detail.asp.

2. HKI. Nutrition and health trends in Indonesia 1999-2003, annual report 2003. Crisis Bulletin, 2004.

3. UNICEF. Global data base on breastfeeding (2000-2007).

4. Swasono M. Ayah perlu dukung ibu menyusui [edisi 2008]. Diunduh dari: http://www.republika.co.id.

5. Widayatun. Keselamatan ibu dan kelangsungan hidup anak: bagaimana partisipasi laki-laki? Buletin Pengkajian Masalah Kependudukan dan Pembangunan. 2001; XII (1).

6. Roesli U. Mengenal ASI eksklusif. Jakarta: Trubus Agriwidya; 2001.

7. Forster. Factors associated with breasfeeding at six months postpartum in a group of Australian women. International Breasfeeding Journal. 2001; 1: 1-8.

8. Susin. Inclusion of fathers in an intervenstion to promote breasfeeding impact on breasfeeding rates. Journal of Human Lactation. 2004; 24 (4): 386-92.

9. Nurpelita. Faktor-faktor yang berhubungan dengan pemberian ASI eksklusif di wilayah kerja Puskesmas Buatan II, Siak, Tahun 2007 [tesis]. Depok: Fakultas Kesehatan Masyarakat, Universitas Indonesia; 2007.

10. Kleinbaum D, Kein M, Pryor ER. Logistic regression: a self learning text. Second Edition. New York: Springer Verlag; 2002.

11. Yanwirasti. Pertumbuhan bayi yang menerima ASI secara eksklusif dan non eksklusif di daerah perkotaan Sumatera Barat. Majalah Kedokteran Indonesia. 2003; 54 (3).

12. Hariyani. Pola pemberian ASI pada bayi usia 0-6 bulan dan faktor-faktor yang mempengaruhinya di Puskesmas Sukarame, Kabupaten Tasikmalaya, Tahun 2008 [tesis]. Depok: Fakultas Kesehatan Masyarakat, Universitas Indonesia; 2008.

13. Asmijati. Faktor-faktor yang berhubungan dengan pemberian ASI eksklusif di Wilayah Kerja Puskesmas Tigaraksa, Kecamatan Tigaraksa, Dati II Tangerang [tesis]. Depok: Fakultas Kesehatan Masyarakat, Universitas Indonesia; 2001.

14. Frinsevae. Hubungan pelayanan konseling menyusui oleh bidan dengan praktek pemberian ASI eksklusif di Kabupaten Katingan, Kalimantan Tengah [tesis]. Depok: Fakultas Kesehatan Masyarakat, Universitas Indonesia; 2008.

15. Lubis NU. Manfaat pemakaian ASI eksklusif. Majalah Cermin Kedokteran. 2000; 26.

16. Perinasia. Manajemen laktasi. Edisi 2. Menuju Persalinan dan Bayi Lahir Sehat. Jakarta; 2004.

17. St John. Meeting the challenge of new fatherhood during the early week. Journal ObstetricGynecol Neonatal Nurs. 2005; 34 (2): 180-9.

18. Kamudoni. Infant feeding practices in the first 6 months and associated factors in a rural and semiurban. Journal of Human Lactation. 2007; 23: 325.

19. Liubai LI, Sujun LI. Feeding practices of infant and their correlates in urban areas of Beijing, China. Pediatrics International. 2003; 45: 400-6. 